\title{
Evaluasi Pewarnaan Kulit Samak Kelinci Mimosa Menggunakan Ekstrak Kulit Buah Naga (Hylocereus polyrhizus)
}

\section{Evaluation of Mimosa Rabbit Leather Dyeing using Dragon Fruit Skin Extract (Hylocereus polyrhizus)}

\author{
W. Pancapalaga* dan N. Nurjannah \\ Program Studi Peternakan, Fakultas Pertanian Peternakan, Universitas Muhammadiyah Malang - \\ Indonesia \\ *Corresponding E-mail: pancapalaga1966@gmail.com \\ (Diterima: 29 Juni 2020; Disetujui: 11 September 2020)
}

\begin{abstract}
ABSTRAK
Pewarnaan merupakan proses akhir pengolahan kulit untuk memperindah penampakan produk kulit tersamak. Pewarnaan kulit pada umumnya dilakukan dengan menggunakan pewarna sintetis, akan tetapi penggunaannya banyak menimbulkan dampak negatif berupa pencemaran pada lingkungan. Tujuan penelitian ini adalah untuk mengevaluasi pewarnaan kulit samak mimosa menggunakan ekstrak kulit buah naga. Materi penelitian ini menggunakan kulit kelinci samak mimosa dan ekstrak kulit buah naga sebagai pewarna alami. Percobaan disusun menggunakan Rancangan Acak Lengkap dengan 4 perlakuan dan 5 kali ulangan. Data kekuatan jahit, kekuatan tarik, kemuluran, dan kelemasan diuji dengan anava dan apabila terdapat pengaruh perlakuan dilanjutkan dengan Uji Wilayah Ganda Duncan. Data untuk ketahanan gosok kering, ketahanan keringat, ketahanan cuci diuji dengan menggunakan penilaian standard grey scale dan dianalisis dengan uji Kruskal Wallis. Perlakuan yang diterapkan adalah perlakuan lama perendaman selama (P1) 30 menit, (P1) 60 menit, (P2) 90 menit, dan (P3) 120 menit. Hasil analisis ragam menunjukkan perlakuan lama perendaman menggunakan ekstrak kulit buah naga dalam pewarnaan kulit samak mimosa memberikan pengaruh yang sangat nyata $(P<0,01)$ terhadap kekuatan jahit, ketahanan gosok kering, ketahanan cuci, ketahanan keringat, kekuatan tarik, dan kekuatan bengkung namun lama perendaman menggunakan ekstrak kulit buah naga dalam pewarnaan kulit samak mimosa memberikan pengaruh yang tidak nyata $(\mathrm{P}>0,05)$ terhadap kemuluran dan kelemasan. Penelitian ini dapat disimpulkan bahwa evaluasi pewarnaan kulit samak mimosa menggunakan ekstrak kulit buah naga yang paling baik dengan lama perendaman selama 120 menit.
\end{abstract}

Kata kunci: pewarnaan, kulit samak, mimosa, ekstrak, buah naga

\section{ABSTRACT}

Dyeing is the final process of processing leather to beautify the appearance of tanned leather products. Skin dyeing is generally done using synthetic dyes, but their use has many negative impacts in the form of pollution to the environment. The purpose of this study was to evaluate the dyeing of mimosa leather using dragon fruit peel extract. The materials of this research were using mimosa leather and dragon fruit peel extract as natural dyes. The experiment was arranged using a Completely Randomized Design with four treatments and five replications. Data on sewing strength, tensile strength, elongation, and fatigue were tested with ANOVA and if there were an effect of the treatments continued with Duncan's Double Region Test. Data the dry rub resistance test, sweat resistance, washing resistance using a standard grayscale assessment and analyzed with the Kruskal Wallis test. The treatments were applied long immersion treatments for 30 minutes (P0), 60 minutes (P1), 90 minutes (P2), and 120 minutes (P3). Results of the analysis of variance showed that the immersion treatment using dragon fruit peel extract in the dyeing of mimosa leather had a very significant effect $(P<0.01)$ on sewing strength, dry rub resistance, washing resistance, sweat resistance, tensile strength, and bending strength but long immersion using dragon fruit peel extract in the coloring of mimosa leather had no significant effect $(P>0.05)$ on elongation and fatigue. 
JPI Vol. 22 (3): 313-320

This study can be concluded that the evaluation of mimosa leather dyeing uses the best dragon fruit peel extract with 120 minutes soaking time.

Keywords: dyeing leather, mimosa, extract, dragon fruit

\section{PENDAHULUAN}

Komiditi ternak yang potensi untuk dikembangkan di Indonesia adalah kelinci. Hal ini bisa dilihat dari data statistik Peternakan dan Kesehatan Hewan (2019) yang menyatakan bahwa jumlah populasi kelinci setiap tahunnya meningkat, di tahun 2019 mencapai 1,13 juta dan $30 \%$ ada di Jawa Timur.

Kulit kelinci banyak diolah menjadi kulit samak dan dijadikan kerajinan barang barang kulit. Kulit samak menjadi lebih awet karena kulitnya telah berikatan dengan bahan kimia sehingga kulit samak lebih stabil dari perlakuan fisik dan kimia. Namun permasalahnnya bahan kimia yang digunakan umumnya berdampak pada lingkungan.

Bahan kimia yang digunakan untuk menyamak kulit hanya $30 \%$ saja yang terikat pada kulit selebihnya terbuang menjadi limbah. Pewarnaan adalah proses finishing penyamakan kulit dengan tujuan untuk meningkatkan keindahan kulit samak (Pancapalaga, 2008). Penggunaan pewarna sintesis pada kulit samak dapat menimbulkan dampak negatif terhadap lingkungan. Oleh karena itu, perlu bahan pewarna alami yang dapat digunakan untuk kulit samak salah satunya adalah pewarna dari kulit buah naga.

Kulit buah naga mengandung zat warna alami antosianin yang cukup tinggi. Penelitian yang telah dilakukan oleh Ingrath et al. (2015) menunjukkan bahwa kadar antosianin pada kulit buah naga sebesar 28,11 $\mathrm{mg} / 100 \mathrm{~g}$. Antosianin merupakan golongan senyawa kimia organik yang dapat larut dalam pelarut polar, serta bertanggung jawab dalam memberikan warna oranye, merah, ungu, biru, hingga hitam (Du et al., 2015). Selanjutnya menurut Lourdes et al. (2013) bahwa Kulit buah naga berpotensi sebagai pewarna alami kulit samak karena menghasilkan warna merah yang dihasilkan oleh pigmen yang bernama antosianin seperti cyanidin-3-sophoroside, dan cyanidin-3-glucoside.

Pewarna alami memiliki ukuran molekul yang lebih kecil, dan mereka tidak memiliki struktur yang linear, selain itu pewarna alami memiliki penetrasi ke serat yang rendah (Maulik and Bhowmik, 2006), Oleh karena itu, lama perendaman menjadikan salah satu faktor yang mempengaruhi hasil dari pewarnaan, sebagaimana penelitian yang pernah dilakukan oleh Gilang et al. (2016) menemukan bahwa perendaman selama 90 menit dengan kosentrasi $10 \%$ mangrove mampu meningkatkan nilai ketahanan gosok cat, kekuatan tarik, kemuluran dan kekuatan sobek sehingga memenui standart SNI.

Penelitian ini bertujuan untuk untuk mengevaluasi pewarnaan kulit samak mimosa menggunakan ekstrak kulit buah naga.

\section{METODE}

\section{Tempat Penelitian}

Ekstrak kulit buah naga dan pengolahan kulit samak dilakukan di Laboratorium Peternakan Universitas Muhammadiyah Malang. Uji kualitas kulit samak dilakukan di Laboratorium Balai Besar Kulit, Karet dan Plastik (BBKKP) Yogyakarta.

\section{Materi Penelitian}

Materi penelitian ini adalah kulit kelinci samak mimosa, ekstrak kulit buah naga, asam sitrat dan air. Sejumlah 25 lembar kulit kelinci Rambon digunakan dalam penelitian ini.

\section{Pelaksanaan Penelitian}

\section{Pembuatan Ekstrak Pewarna Alami}

Proses ekstrak pewarna alami dari kulit buah naga pertama kali dilakukan 
sebagai berikut: menimbang kulit buah naga, selanjutnya kulit buah naga dipotong potong kecil kecil dan diblender. Kulit buah naga yang sudah halus di rendam dalam larutan asam sitrat dengan ratio (1:2) antara asam sitrat dan aquades. Kemudian dipisahkan atara rendemen dan ampas dengan cara menyaring, ekstrak kulit buah naga yang dihasilkan untuk pewarna alami.

\section{Pembuatan Kulit Samak Kelinci}

Proses Kulit samak Kelinci, pertama kali kulit direndam dalam larutan kapur, dengan menambahkan air 400\% kedalam drum pemutar, ditambah $2 \% \mathrm{Na}_{2} \mathrm{~S}$, dan $4 \%$ kapur. Kemudian diputar selama 1 jam dan di rendam semalam. Esoknya bulunya dikerok sampai bersih. Dilanjutkan proses penghilangan kapur dengan cara penambahan asam sulfat sebanyak $0,75 \%$. Selanjutnya proses bating, dengan cara memasukkan air hangat $40^{\circ} \mathrm{C}$ sebanyak $100 \%$ dari berat kulit kedalam drum dan ditambah orophon 1\% diputar selama 2 jam. Terakhir dilakukan Proses penyamakan yaitu dengan penambahan $100 \%$ air dengan suhu $40^{\circ} \mathrm{C}$, ditambahkan mimosa $20 \%$ diberikan secara bertahap $(5 \%, 5 \%$, dan $10 \%)$ masing masing tahapan diputar selama 30 menit. Selanjutnya dilakukan pewarnaan dengan ekstrak kulit buah naga, sesuai perlakuan yaitu: $\mathrm{P} 0=$ Lama perendaman 30 menit, $\mathrm{P} 1$ = Lama perendaman selama 60 menit, P2 = Lama perendaman selama 90 menit, dan P3 = Lama perendaman selama 120 menit.

\section{Peubah Yang Diamati}

\section{Kekuatan Jahit}

Uji kekuatan jahitdengan menggunakan metode Standard Nasional Indonsia (SNI 061117-1989), alat tensile strength tester.

\section{Kekuatan Tarik dan Kemuruluran Kulit Samak}

Uji Kekuatan tarik dan kemuluran kulit dengan metode Standard Nasional Indonsia (SNI. 06-1795-1990) dengan alat test kekuatan tarik (Strength Tester). Kekuatan tarik adalah besarnya gaya maksimal yang diperlukan untuk menarik kulit sampai putus dinyatakan dalam $\mathrm{N} / \mathrm{cm}^{2}$ sedangkan kemuluran kulit adalah pertambahan panjang kulit pada saat ditarik sampai putus dibagi dengan panjang semula dinyatakan dalam persen (\%).

\section{Kelemasan Kulit}

Pengukuran kelemasan menggunakan alat softness tester. Sampel harus bebas dari kerusakan fisik yang nyata seperti sobek didaerah dimana kelemasan yang akan diukur. Metode uji kelemasan kulit menggunakan metode (IUP/36).

\section{Ketahanan Warna terhadap Gosokan}

Uji ketahanan gosok dengan metode Standar Nasional Indonesia (SNI-08-02881998) dengan alat crockmeter. Pengujian dilakukan dengan membandingkan penodaan warna pada kain penggosok dengan grey scale.

\section{Ketahanan Cuci}

Uji ketahanan cuci menggunakan metode SNI 08-0288-1998. Alat yang digunakan laundymeter. Pengujian dilakukan dengan membandingkan hasil kulit yang dicuci dengan standar perubahan warna pada Gray Scale.

\section{Ketahanan Keringat}

Uji ketahanan keringat menggunakan metode SNI 105-E04:2010.

\section{Ketahanan Bengkung}

Kekuatan bengkung ialah banyaknya tekukan yang dibutuhkan untuk membuat retak permukaan lapisan nerf. Cara pengukuran untuk menguji ketahanan bengkung menggunakan crockmeter yang mempunyai jari dengan diameter $(1,6 \pm 0,01)$ $\mathrm{cm}$ yang bergerak satu kali maju mundur sejauh $(10,4 \pm 0,3) \mathrm{cm}$ setiap kali putaran, dengan gaya tekanan pada kulit sebesar $(900 \pm 20)$ gram sesuai SNI ISO 5402.

\section{Rancangan Percobaan}

Percobaan ini menggunakan Rancangan Acak Lengkap (RAL). Penelitian ini menggunakan 4 perlakuan dan ulangan sebanyak 5 kali. Perlakuan yang diberikan dalam penelitian ini adalah $\mathrm{P} 0=$ Lama perendaman 30 menit, P1 = Lama perendaman selama 
60 menit, P2 = Lama perendaman selama 90 menit dan P3 = Lama perendaman selama 120 menit. Data kekuatan jahit, kekuatan tarik, kemuluran yang diperoleh dianalisa dengan ANOVA, jika terdapat pengaruh terhadap peubah yang diukur, maka akan dilanjutkan dengan uji DMRT. Sedangkan data ketahanan warna terhadap gosokan, ketahanan cuci, ketahanan keringat, kekuatan bengkung dan kelemasan dianalisis dengan Kruskal Wallis untuk menentukan adanya perbedaan yang signifikan dan dilanjutkan dengan Mann Whitney.

\section{HASIL DAN PEMBAHASAN}

\section{Kekuatan Jahit}

Uji kekuatan jahit dilakukan guna mengetahui beban maksimum yang dibutuhkan untuk memutuskan jahitan pada kulit kelinci tersamak mimosa. Lama perendaman dengan ekstrak kulit buah naga memberikan pengaruh yang sangat nyata $(\mathrm{P}<0,01)$ terhadap kekuatan jahit kulit kelinci samak mimosa (Tabel 1), hal ini kemungkinan disebabkan karena semakin lama di rendam dalam ekstrak kulit buah naga menyebabkan adanya peningkatan keasaman pada kulit samak mimosa. Peningkatan keasaman ini merubah struktur protein kolagen dalam kulit samak.

Kanagy (1977) menyatakan bahwa kekuatan jahit dapat dipengaruhi oleh ketebalan kulit, kandungan dan kepadatan protein kolagen, besarnya sudut jalinan serabut kolagen dan ketebalan korium Kekuatan jahit berbanding lurus dengan kekuatan tarik dan kekuatan sobek, bila kekuatan tarik dan kekuatan sobek tinggi maka kekuatan jahit juga tinggi. Kulit yang tipis mempunyai serat kolagen yang longgar sehingga mempunyai daya sobek yang lebih rendah jika dibandingkan dengan kulit yang lebih tebal. Nilai kekuatan jahit dengan lama perendaman 120 menit sebesar $52,81 \mathrm{~kg} / \mathrm{cm}$, nilai ini sudah memenuhi Standard Nasional Indonesia SNI 4593:2011 Kulit Jaket Domba/ kambing yang batas minimum kekuatan jahit kulit kambing (glace) minimum sebesar 50 $\mathrm{kg} / \mathrm{cm}$.

\section{Kekuatan Tarik dan Kemuruluran Kulit Samak}

Sifat fisik kulit tersamak yang sangat penting adalah kekuatan tarik dan kemuluran kulit samak. Kekuatan tarik adalah beban maksimum dari per satuan luas yang dibutuhkan untuk menarik contoh uji sampai putus dan dinyatakan dalam $\mathrm{kg} / \mathrm{cm}^{2}$. Sedangkan kemuluran adalah pertambahan panjang kulit pada saat ditarik sampai putus dibagi dengan panjang semula dinyatakan dalam persen. Persentase kemuluran kulit samak yang diuji menunjukkan elastisitas kulit samak. Kulit yang memiliki kemuluran tinggi memungkinkan kulit untuk tidak mudah robek atau rusak selama penggunaannya (Suparno et al., 2011).

Lama perendaman dengan ekstrak kulit buah naga memberikan pengaruh yang sangat nyata $(\mathrm{P}<0,01)$ terhadap kekuatan tarik kulit kelinci samak mimosa (Tabel 1), hal ini disebabkan karena semakin lama direndam dalam ekstrak kulit buah naga akan memberikan kesempatan zat warna yang ada di ekstrak kulit buah naga untuk terikat pada permukaan kulit semakin banyak, sehingga proses pewarnaan menjadi sempurna. Dengan demikian juga akan meningkatkan ikatan protein kolagen dalam kulit samak, hal ini menyebabkan kekuatan tarik semakin tinggi dan semakin tinggi nilai kekuatan tarik, semakin baik kulit samak yang dihasilkan.

Menurut Triatmojo (2012) bentuk anyaman kepadatan berkas serabut kolagen, keutuhan serabut kolagen dan sudut anyaman ikut menentukan besarnya kekuatan tarik dan kemuluran kulit. Kulit yang kekuatan tariknya tinggi pada umumnya kemulurannya rendah, sedangkan yang kekuatan tariknya rendah kemulurannya tinggi. Hal tersebut terbukti pada nilai kemuluran, dimana lama perendaman dengan ekstrak kulit buah naga tidak berpengaruh $(\mathrm{P}>0,05)$ terhadap kemuluran kulit kelinci samak mimosa 
Tabel 1. Nilai Rataan Kekuatan Jahit, Kekuatan Tarik, Kemuluran, dan Kelemasaan Kulit Kelinci Samak Mimosa setelah Direndam dengan Ekstrak Kulit Buah Naga

\begin{tabular}{lrrrr}
\hline \multirow{2}{*}{ Karakteristik } & \multicolumn{4}{c}{ Lama perendaman (menit) } \\
\cline { 2 - 5 } & $30^{\prime}$ & $60^{\prime}$ & $90^{\circ}$ & $120^{\prime}$ \\
\hline Kekuatan jahit $(\mathrm{N} / \mathrm{cm})$ & $18,21^{\mathrm{a}}$ & $23,05^{\mathrm{a}}$ & $23,68^{\mathrm{a}}$ & $52,81^{\mathrm{b}}$ \\
Kekuatan Tarik $\left(\mathrm{kg} / \mathrm{cm}^{2}\right)$ & $109,37^{\mathrm{a}}$ & $112,23^{\mathrm{a}}$ & $113,99^{\mathrm{ab}}$ & $122,96^{\mathrm{b}}$ \\
Kemuluran $(\%)$ & $25,95^{\mathrm{a}}$ & $23,79^{\mathrm{a}}$ & $24,31^{\mathrm{a}}$ & $17,55^{\mathrm{a}}$ \\
Kelemasan $(\mathrm{mm})$ & $2,09^{\mathrm{a}}$ & $2,55^{\mathrm{a}}$ & $2,56^{\mathrm{a}}$ & $2,30^{\mathrm{a}}$ \\
\hline
\end{tabular}

Keterangan: Huruf superskript menandakan berbeda nyata $(\mathrm{P}<0,05)$

(Tabel 1), hal ini berarti bahwa semakin lama direndam dalam ekstrak kulit buah naga, nilai kemuluran kulit samak sama saja. Hal ini menunjukan bahwa perendaaman kulit kedalam ekstrak kulit buah naga tidak menyebabkan perubahan struktur kulit, karena struktur kulit terutama pada korium kulit sudah terikat oleh bahan penyamak.

\section{Kelemasan Kulit}

Seperti halnya pada kemuluran, kelemasan kulit menunjukan bahwa lama perendaman dengan ekstrak kulit buah naga tidak berpengaruh terhadap kelemasan kulit kelinci samak mimosa $(P>0,05)$ hal ini kemungkinan karena perendaman kulit buah naga tidak bisa merubah struktur kulit sehingga kepadatan kulit tetap. Selain itu kelemasan kulit dipengaruhi oleh air, lemak, struktur serabut dan ketebalan kulit (Hasan et al., 2014). Berati dengan perendaman ekstrak kulit buah naga meskipun lama tidak akan mendegradasi serabut serabut kulit. Lebih jauh dikatakan oleh Mustakim et al. (2007) bahwa degradasi kulit akan menyebabkan kekakuan kulit karena denaturasi dan terjadi gelatinisasi serabut serabut kulit.

\section{Ketahanan Warna terhadap Gosokan}

Berdasarkan hasil analisa Kruskal Wallis diperoleh bahwa lama perendaman dengan ekstrak kulit buah naga memberikan perbedaan yang nyata $(\mathrm{P}<0,05)$ terhadap ketahanan gosok basah kulit kelinci samak mimosa. Setelah diuji lanjut dengan uji Mann Whitney menunjukkan bahwa lama perendaman dengan 120 menit memberikaan ketahanan gosok yang baik dengan nilai 5 (tidak luntur).

Kusriniati et al. (2008) menyatakan bahwa ketahanan luntur warna merupakan perubahan warna karena suatu sebab sehingga gradasi warnanya berubah atau luntur, ketahanan luntur warna mengarah pada kemampuan warna untuk tetap stabil dan tidak berubah. Semakin lama direndam dengan ekstrak kulit buah naga maka akan memberikan kesempatan ikatan zat warna yang ada pada antosianin untuk berikatan sempurna dengan protein kolagen yang ada di permukaan kulit samak. Hal ini juga disebaban karena semua gugus kation dan anion pada kulit sudah sepenuhnya berikatan dengan gugus kation dan anion yang ada pada zat pewarna ekstrak kulit buah naga sehingga perendaman pewarna dengan waktu yang lebih panjang akan lebih sempurna. Hasil ini sesuai dengan yang dilakukan oleh Penelitian lain yang telah dilakukan oleh Liyandari (2000) yang menemukan bahwa lama perendaman pada proses pewarnaan membutuhkan waktu fiksasi 90 menit, karena akan memberikan nilai ketahanan luntur warna sangat baik yaitu mencapai 5(tidak luntur).

\section{Ketahanan Warna terhadap Cucian}

Lama perendaman dengan ekstrak kulit buah naga memberikan perbedaan yang nyata $(\mathrm{P}<0,05)$ terhadap ketahanan cuci kulit kelinci samak mimosa (Tabel 2). Kuatnya ketahanan cuci kulit samak mimosa yang diwarnai dengan ekstrak kulit buah naga disebabkan perbedaan molekul antara struktur permukaan dan ekstrak kulit buah naga. Menurut Reda et al. (2006) zat warna asam mempunyai gugusan 
Tabel 2. Hasil Kruskal Wallis pada Perlakuan Lama Perendaman Ekstrak Kulit Buah Naga yang Berbeda

\begin{tabular}{lcccc}
\hline Perlakuan & Nilai Chi -Square & Df & Asynp.sig & Kesimpulan \\
\hline $\begin{array}{l}\text { Kethanan } \\
\text { Gosok Basah }\end{array}$ & 11,000 & 3 & 0,012 & $\begin{array}{c}\text { ada perbedaan yang nyata } \\
(\mathrm{P}<0,05)\end{array}$ \\
$\begin{array}{l}\text { Ketahanan } \\
\text { Cucian }\end{array}$ & 9,488 & 3 & 0,023 & $\begin{array}{c}\text { ada perbedaan yang nyata } \\
(\mathrm{P}<0,05)\end{array}$ \\
$\begin{array}{l}\text { Ketahanan } \\
\text { Keringat }\end{array}$ & 10,530 & 3 & 0,015 & $\begin{array}{c}\text { adanya perbedaan yang nyata } \\
(\mathrm{P}<0,05)\end{array}$ \\
$\begin{array}{l}\text { Kekuatan } \\
\text { Bengkung }\end{array}$ & 15,546 & 3 & 0,001 & $\begin{array}{c}\text { adanya perbedaan yang nyata } \\
(\mathrm{P}<0,05)\end{array}$ \\
\hline
\end{tabular}

pelarut yang sama jumlahnya dan ketahanan pencucian sebagian besar ditentukan oleh berat molekul atau ukuran besar molekulnya. Molekul yang besar akan mempunyai ketahanan pencucian yang lebih baik. Hal diperkuat pendapat oleh Kwartiningsih et al. (2016) zat warna asam mempunyai ketahanan cuci dan ketahanan sinar yang baik. Sifat ketahanan tersebut sangat dipengaruhi oleh berat molekul dan konfigurasinya

\section{Ketahanan Warna terhadap Keringat}

Lama perendaman dengan ekstrak kulit buah naga memberikan perbedaan yang nyata $(\mathrm{P}<0,05)$ terhadap ketahanan keringat kulit kelinci samak mimosa (Tabel 2). Hasil uji Mann Whitney lama perendaman dengan 120 menit membuat warna kulit tidak luntur karena keringat hal ini karena adanya asam sitrat yang menyebabkan kuatnya fiksasi bahan pewarna kulit buah naga pada kulit samak. Asam sitrat yang terkandung dalam ekstrak kulit buah naga juga berfungsi sebagai fiksator yang membantu meningkatkan sifat ketahanan luntur hal ini sesuai dengan pendapat Riawan (2006) penggunaan zat fiksatif yang memiliki $\mathrm{pH}$ yang lebih asam dibandingkan $\mathrm{pH}$ zat warna akan memperbaiki sifat ketahanan luntur warna.

\section{Ketahanan Bengkung}

Berdasarkan hasil analisa Kruskal Wallis diperoleh bahwa lama perendaman dengan ekstrak kulit buah naga memberikan perbedaan yang nyata $(\mathrm{P}<0,05)$ terhadap ketahanan bengkung kulit kelinci samak mimosa. Ketahan bengkung mengindikasikan banyaknya keretakkan dibagian permukaan kulit lapisan papilarae yang telah diwarnai akibat dari tekukan selama pemakaian kulit. Dari hasil penelitian semakin lama direndam dengan esktrak kulit buah naga maka kulit kelinci samak mimosa semakin tahan tekukan artinya yang retak sedikit hal ini disebabkan karena selama dalam perendaman tidak merusak kadar lemak kulit hal ini terbukti dari hasil kelemasan kulit juga tidak berubah. Lemak didalam kulit akan mempengaruhi ketahanan bengkung kulit samak. Jika lemak di dalam kulit tinggi, ketahanan kulit terhadap tekukanakan tinggi. Sebaliknya jika lemak rendah, ketahanan kulit terhadap tekukan akan rendah (Triatmojo, 2012).

\section{KESIMPULAN}

Lama perendaman selama 120 menit dengan ekstrak kulit buah naga membuat kulit samak kelinci mimosa tidak luntur karena gososkan basah, karena cucian, karena keringat dan tidak retak karena tekukan, selain itu kulit samak lebih kuat dari sobekan terkena jahitan dan kuat tariknya tinggi.

\section{DAFTAR PUSTAKA}

Du, H., Wu, J., Ji, K. X., Zeng, Q. Y., Bhuiya, M. W., Su, S., Shu, Q. Y., Ren, H. X., Liu, Z. A. and Wang, L. S. 2015. Methylation Mediated by An 
Anthocyanin, O-Methyltransferase, Is Involved in Purple Flower Coloration in Paeonia. Journal of Experimental Botany. 66(21): 6563 - 6577.

Gilang, V. Hariyadi, P. dan Wijayanti, P. 2016. Aplikasi Kulit Kayu Mangrove (Rhizopora Sp.) Sebagai Alternatif Pewarnaalami pada Kulit Samak Ikan Nila (Oreochromis niloticus) Prosiding Seminar Nasional Kulit, Karet, dan Plastik Ke-5 Yogyakarta. Hlm.115-127.

Hassan, E. A., Ibrahim, M. T. and Sally, K. A. 2014. Optimisation of chrome retanning process to the garad (Acacia nilotica) tanned leather. Journal of Science and Technology. 15(1): 87-94.

Ingrath, W., Nugroho., A. Wahyunanto, dan Yulianingsih, R. 2015. Ekstraksi Pigmen Antosianin dari Kulit Buah Naga Merah (Hylocereus costaricensis) sebagai Pewarna Alami Makanan dengan Menggunakan Microwave (Kajian Waktu Pemanasan dengan Microwave dan Penambahan Rasio Pelarut Aquades dan Asam Sitrat). Universitas Brawijaya. Malang.

Kanagy, J. R. 1977. Physical and Performance Properties of Leather. In The Chemistry and Technology of Leather Vol. 4. Ed. By O'Flaherty F., W.T. Roddy and R.M. Lollar. Krieger Publishing Company. Florida.

Kasmujiastuti, E. 2006. Penggunaan Zat Warna Alam Untuk Kulit Non Konvensional. Majalah Kulit Karet dan Plastik Vol. 22 No 1. Balai Besar Kulit, Karet dan Plastik. Hlm.20-25.

Kusriniati, D., E. Setyowati, dan U. Achmad. 2008. Pemanfaatan Daun Sengon (Albizia falcataria) sebagai Pewarna Kain Sutera Menggunakan Mordan Tawas dengan Konsentrasi yang Berbeda. Fakultas Teknik UNNES. Semarang.

Kwartiningsih, E., Prastika, A. K. dan Triana, D. L. 2016. Ekstraksi dan Uji Stabilitas Antosianin dari Kulit Buah Naga Super
Merah (Hylocereus costaricensis). Universitas Sebelas Maret. Surakarta.

Liyandari. 2000. Pewarnaan Batik Fadma. Skripsi. Universitas Islam Indonesia. Yogyakarta.

Maulik, S. R. and Bhowmik, K. I. 2006. Studies onapplication of some vegetable dyes on cellulosic and lignocellulosic fibre. Man-Made Textiles in India. 49(4): 142.

Lourdes, M. D., Tamayo, C. J. A., Duch, E. S., Lizama, A. P. and Herrera, M. C. H. 2013. Extraction and Stability of Anthocyanins Present in the Skin of the Dragon Fruit (Hylocereus undatus). Food and Nutrition Sciences. 4: 12211228.

Mustakim., I. Toharin, dan I. A. Rosyida. 2007. Tingkat Penggunaan Bahan Samak Chrome pada Kulit Kelinci Samak Bulu Ditinjau dari Kekuatan Sobek, Kekuatan Jahit, Penyerapan Air dan Organoleptik. Jurnal Ilmu dan Teknologi Hasil Ternak. 2(2): 14-27.

Pancapalaga, W. 2008. Ilmu Teknologi Pengolaha Kulit. UMM Press. Malang.

Reda. Nassar dan Nahed. 2006. Anionic Colouration of acrylic Fibre part II: Printing with reactive, acid and direct dyes. J. Dyes and Pigments. 74 (2): 215222.

Riawan, I., E. Hartoyo, dan S. Rukmini. 2006. Panduan Tekstil dan Evaluasi Tekstil. Museum Tekstil DKI Jakarta.

Statistik Peternakan dan Kesehatan Hewan. 2019. Direktorat Jenderal Peternakan dan Kesehatan Hewan. Kementrian Pertanian.

SNI 06-0996. 1989. Pengujian Ketahanan Warna terhadap Gosokan.

SNI 06-1117. 1989. Pengujian Kekuatan Jahit.

SNI 06-4586-1998. Kulit Jadi dari Kulit Ular Air Tawar Samak Krom.

SNI ISO 5402. Kulit - Penentuan ketahanan bengkuk - Bagian 1: Metode flexometer. 
ISO 17235: 2011(E) IULTCS/IUP 36: 2011(E). Leather - Physical and Mechanical Tets- Determination of Softnes.

SNI 105-E04. 2010. Cara Uji Tahan Luntur Warna terhadap Keringat.

Suparno, O., Gumbira-Sa'id, E., Kartika, I. A., Muslich, and Amwaliya, S. 2012. Chamois Leather Tanning Accelerated by Oxidizing Agent. Jurnal Teknik
Kimia Indonesia. 11(1): 9-16.

Triatmojo, S. 2012. Teknologi Pengolahan Kulit Sapi. PT. Citra Aji Parama. Yogjakarta.

Triatmojo, S. dan Abidin, M. Z. 2014. Penyamakan Kulit Ramah Lingkungan Gadjah Mada University Press. Yogyakarta. Cetakan pertama. 